\title{
The evolution of the international peace architecture
}

\author{
Oliver P. Richmond* \\ Department of Politics, University of Manchester, Manchester, United Kingdom \\ *Corresponding author: Email: oliver.richmond@manchester.ac.uk
}

(Received 9 September 2020; revised 9 April 2021; accepted 20 April 2021; first published online 4 June 2021)

\begin{abstract}
The theories and doctrines related to peacekeeping, mediation, peacebuilding, and statebuilding, as well as other tools used to end war and conflict, raise a range of long-standing questions about the evolution and integrity of what might be called an international peace architecture. A narrow version of this term has begun to appear in the context of peacebuilding through the United Nations, the African Union, the European Union, other regional actors, the international legal system, and the International Financial Institutions. This article proposes a much broader, historical version, with six main theoretical stages, which have, from a critical perspective, produced a substantial, though fragile, international architecture.
\end{abstract}

Keywords: Peace Processes; Peacebuilding; International System; International Architecture

The political forms that we once knew - the nation-state, sovereignty, democratic participation, political parties, international law - have come to the end of their history. They remain part of our lives as empty forms, but contemporary politics assumes the form of an 'economy', that is, a government of things and of men. ${ }^{1}$

\section{Introduction}

During the last century, the construction and evolution of an assemblage that can be described as an 'international peace architecture' (IPA) has spanned the local, state, and global scales of international relations. This architecture is far more extensive than the UN Peacebuilding Architecture this term is usually used to refer to. It spans a wide range of international, state, and nongovernmental actors, civil society and social movements and has gathered pace since at least the seventeenth century (though it predates this period in theoretical and practical terms, of course).

From a critical perspective of power, political order, and legitimacy every political system requires complex systems to maintain itself, consciously or subconsciously, against threats, risks, and paradoxes as well as to prop up its legitimacy. Such systems require knowledge, power, innovation, intergenerational maintenance, and very significant investment in long-term institutions that reflect everyday political claims for order and sustainability. ${ }^{2}$ In the case of the IPA, this is represented by a wide, political formulation spanning at least the last three hundred years. It formed through twin processes to combat war and violence: frameworks that are historically linear (Whiggish state, legal, and institutional development) ${ }^{3}$ and rhizomatic (the more

\footnotetext{
${ }^{1}$ An interview with Giorgio Agamben, 'God didn't die, he was transformed into money', Peppe Savà, available at: \{http:// libcom.org/library/god-didnt-die-he-was-transformed-money-interview-giorgio-agamben-peppe-sav\%C3\%A0\} accessed 10 February 2014.

${ }^{2}$ Joseph A. Tainter, The Collapse of Complex Societies (Cambridge, UK: Cambridge University Press, 1988), p. 37.

${ }^{3}$ Mark Mazower, Governing the World (London, UK: Penguin, 2012); Mark Mazower, No Enchanted Palace: The End of Empire and the Ideological Origins of the United Nations (Princeton, NJ: Princeton University Press, 2009).

(c) The Author(s) 2021. Published by Cambridge University Press on behalf of the British International Studies Association. This is an Open Access article, distributed under the terms of the Creative Commons Attribution licence (http://creativecommons.org/licenses/by/4.0/), which permits unrestricted re-use, distribution, and reproduction in any medium, provided the original work is properly cited.
} 
complex and entangled, critical development of rights according to expanding subaltern claims). ${ }^{4}$

This has occurred in the context of a world order subject to multiple forms of civil, state, and international violence and war, not least systemic 'fragmegration' (in which systems are subject to conflicting forces causing both integration and fragmentation, as the quotation above alludes to). ${ }^{5}$ Overall, the architecture represents an attempt to respond to the aftermath of different types of war while maintaining Western and Northern hegemony, to support the construction of a social state, and international framework capable of overcoming war's causal roots, and to support a dynamic, networked peace from a subaltern perspective that transcends old injustices, losses, boundaries, and hierarchies. ${ }^{6}$ Several of these goals are contradictory: the IPA combines both emancipatory and hegemonic frameworks, in which ideological contestation of political and international order have not been resolved.

This article argues that subsequently a grand edifice has emerged, from local to global scales, which though fragile and unstable, offers some prospects for further development. It raises a range of long-standing, critical questions about the evolution and integrity of the IPA. This is a term that has begun to appear in the context of peacebuilding in the UN (the UN Peacebuilding Commission, for example): ${ }^{7}$ with the African Union's strategy related to peacebuilding across the sub-Saharan region; ${ }^{8}$ as well as a term referring to the broader constellation or alphabet soup of international actors, from transitional civil society, to the UN system, the EU, OSCE, NATO, other regional actors, the international legal system, and the IFIs.

This article first offers an overview of the IPA in theoretical terms, before examining each historical-theoretical stage in its development. Though this outline is chronological, it also allows for a critical genealogy to emerge exposing the implications of the evolution of the international system for peace. ${ }^{9}$ It outlines some of the challenges and 'blockages' this system has faced, especially with the development of stage five in the context of the recent war on terror and statebuilding. It then outlines the implications for a new stage, which has to deal with new modes of violence in IR. It concludes with an evaluation of the architecture's functionality and stability, and discusses what it means for how contemporary peace has developed as a concept.

\section{Critical approaches to the IPA}

The emergence of an IPA is partly a consequence of an historical evolution to combat war and associated forms of political violence in its evolving forms, through which there have been six main stages or layers, often overlapping. Partly it represents a linear process that can be traced in systemic layers that have built up to combat war, and can be seen through standard liberal theories and methods. Partly it represents different global, regional, and state forms of hegemony, and partly it represents the circulation of critical and subaltern agency and the political claims made for emancipation in a rhizomatic framework. The development of each stage is also a response to the failures of the previous stage as well as representing attempts to engage with global structural change and new forms of conflict and violence that are constantly emerging. Most importantly, each stage is a vehicle for the expansion of subaltern and human rights claims across the international system, which has influenced the development of the social contract, the nature

\footnotetext{
${ }^{4}$ Gilles Deleuze and Felix Guattari, A Thousand Plateaus (Minneapolis, MN: University of Minnesota Press, 1987).

${ }^{5}$ James N. Rosenau, Along the Domestic-Foreign Frontier: Exploring Governance in a Turbulent World, Cambridge Studies in International Relations (Cambridge, UK: Cambridge University Press, 1997).

${ }^{6}$ Michel Foucault, 'Of other spaces, heterotopias' (1967), in Architecture /Mouvement/ Continuité (October 1984) trans. Jay Miskowiec, pp. 46-9. See also General Assembly Resolution, A/RES/70/262, 'Review of the United Nations Peacebuilding Architecture', 12 May 2016, adopted by the General Assembly on 27 April 2016.

${ }^{7}$ For an excellent diagrammatic map of the UN's peacebuilding architecture and its complex organisation, as well as its shifting nature, see Fernando Cavalcante, Peacebuilding in the United Nations (London, UK: Palgrave, 2019), p. 222.

${ }^{8}$ Siphamandla Zondi, 'African Union approaches to peacebuilding: Efforts at shifting the continent towards decolonial peace', African Journal on Conflict Resolution, 17:1 (2017), pp. 105-31 (p. 110).

${ }^{9}$ Michel Foucault, 'What is critique?', in Sylvère Lotringer (ed.), The Politics of Truth (New York, NY: Semiotext(e), 2007).
} 
of the state, and international order itself. ${ }^{10}$ Each stage carries its own ontologies, epistemological framing, empirical examples, and methods.

Shedding light on the development of the IPA, using a critical-historical methodology ${ }^{11}$ aimed at underlining the mutual interweaving and construction of subaltern, state, and international political frameworks (which incorporate emancipatory claims, constitutions, law, and institutions) helps to understand the evolution of an overall historical IPA framework. This is rather than focusing solely on power, sovereignty, territory, and perhaps diplomacy. It also helps situate order-maintenance methods and tools such as peacekeeping, conflict transformation, peacebuilding, or statebuilding. It helps understand the types of peace that have been the goal at each stage, the pressures on them, and how they may advance.

In terms that are relative to the conditions and outcomes of war, the most successful international and state level peace architecture in modernity was the liberal peace framework, albeit only in relative terms to the systems of geopolitics, imperialism, civil and industrial war that it contended with. The systems of power and interest were modified by its ethical systems of rights and duties, but still depended upon on a long-standing geopolitical balance of power or hegemonic support. Yet, soon after its post-Cold War apogee, the liberal peace system was reshaped from above and below by international and local actors engaged in peacebuilding and a range of other peace related activities. ${ }^{12}$ They incorporated military intervention, liberal democratic and capitalist state reform of conflict-affected states, in many countries as diverse as Cambodia, Timor Leste, Sierra Leone, DRC, Liberia, El Salvador, Bosnia and Kosovo. ${ }^{13}$ The liberal peace framework was a substantial stage in the IPA, a flawed one that required propping up. There are several lines of critique that emerged: that liberal peace watered down rights and equality, was not concerned with sustainability or broader forms of justice, marginalised grounded legitimacy, resolved wars in support of Western hegemonic order, and could not hold its position in the IPA.

However, from a more critical perspective, foregrounding ethical questions about political order where power and knowledge determine war and peace, pointed to the validity of alternative forms of organisation. These were inherent in hybrid political orders, resistance, and the hidden workings of power and stratification, as mounting dysfunctionality drove the subsequent 'local turn'. ${ }^{14}$ This set of approaches pointed to the salience not just of geopolitics and diplomacy, political-economy, or even liberal internationalism for peacemaking, but also everyday and hybrid forms of peace from a postcolonial perspective. ${ }^{15}$ This approach was in parallel to the postcolonial interest in alternative types of international order. ${ }^{16}$ This approach has been divided between descriptive, prescriptive, and emancipatory approaches. ${ }^{17}$

\footnotetext{
${ }^{10}$ This article uses the concept of rights claims to span political claims for basic human rights and their expansion through several further generations of rights, including the right to have rights. See the very comprehensive argument in Jean L. Cohen, Globalisation and Sovereignty (Cambridge, UK: Cambridge University Press, 2012), pp. 159-222.

${ }^{11}$ See, for example, Nick Vaughan-Williams, 'International Relations and the "problem of history"', Millennium, 34:1 (2005), pp. 115-36.

${ }^{12}$ Roland Paris, At War's End (Cambridge, UK: Cambridge University Press, 2004), among others, outlined the course of this argument early on the in the post-Cold War debates, based on a critique of liberal peace because of its unsuitable political and economic dimensions. This was essentially an argument for a more trusteeship-oriented approach to liberal peacebuilding.

${ }^{13}$ For an early selection of comparative case studies on hybrid peace outcomes, see Oliver P. Richmond and Jason Franks, Liberal Peace Transitions (Edinburgh, UK: Edinburgh University Press, 2008). David Chandler's study, Peacebuilding: The Twenty Years' Crisis, is probably the best overview of the longer-term course of the debates. David Chandler, Peacebuilding: The Twenty Years' Crisis, 1997-2017 (London, UK: Palgrave, 2017).

${ }^{14}$ Roger Mac Ginty and Oliver P. Richmond, 'The local turn in peace building: A critical agenda for peace', Third World Quarterly, 34:5 (2013), pp. 763-83.

${ }^{15}$ Oliver P. Richmond, A Post-Liberal Peace (London, UK: Routledge, 2011).

${ }^{16}$ Adom Getachew, Worldmaking After Empire (Princeton, NJ: Princeton University Press, 2019), pp. 18, $24,40$.

${ }^{17}$ Oliver P. Richmond, 'Interventionary order and its methodologies: The relationship between peace and intervention', Third World Quarterly, 41:2 (2020), pp. 207-27.
} 
Much evidence was found for the development of hybrid peace processes driven by local agency, ${ }^{18}$ determined to reclaim some version of an emancipatory peace in the subsequent marriage of institutional and ethnographic research as an emancipatory response to more dominant problem-solving approaches or more banal descriptive approaches. ${ }^{19}$ This process in turn has led to a discussion in the academic and policy literatures of postcolonial and intersectional questions of everyday and critical agency, micro-politics, justice, power, and the encounter of everyday peace formation with international peacebuilding actors, along with the mediating role of local and global civil society. ${ }^{20}$ The local turn has once again turned attention to the deficiencies of the international system, power relations, and related injustices, and the need for substantial reform in the light of the recent 'Sustaining Peace' agenda of the UN. It is partly because of the plurality of perspectives of peace in IR that now exist that the IPA has become more clearly discernible, as the next section illustrates.

\section{An overview of the IPA: A historical sketch and disaggregation}

Though very opaque, it is possible to see in the debates about peace in international relations over the last century, an approximation of a systematic approach, even if it is only the sum of a range of micro-tools such as diplomacy, peacekeeping, mediation, law, peacebuilding, statebuilding, and global governance. During the last one hundred years, the liberal peace model has been by far the most dominant concept of and institutional framework for peace. However, a much broader international architecture has emerged in various stages, of which the liberal peace is just one component.

Overall, it comprises a range of concepts, methods, and theories that are ontologically framed by Western assumptions inherent in thinking about war and peace in several stages. They effectively represent sedimental layers, like a palimpsest ${ }^{21}$ (in which a previous text is visible under a newer, overwritten text), built up over time through broadening forms of intervention created to maintain an ever more complex IPA. ${ }^{22}$ Each layer redresses a previous set of conflict igniters and coexist with (or contradict) the new layers that emerge for later forms of conflict, such as feudalism, imperialism and colonialism, capitalism and industrialism, the national state, cold war, ethnic and religious conflict, and 'new wars'. ${ }^{23}$ Underlying this essentially unplanned evolution is both a linear process and also fluid and rhizomatic dynamics. ${ }^{24}$

There has always been a long-standing local and international political dream of a positive peace, one that transcends coexistence and builds a new ethical framework for cooperation and equalisation of widely divergent human populations. As Kant wrote, in a universal community wrongs committed in one place are felt everywhere. ${ }^{25}$ Much of the body of thinking and

\footnotetext{
${ }^{18}$ Oliver P. Richmond, 'Peace formation and local infrastructures for peace', Alternatives: Global, Local, Political, 38:4 (2013), pp. 271-87.

${ }^{19}$ Michael Pugh, 'The political economy of peacebuilding: A critical theory perspective', International Journal of Peace Studies, 10:2 (2005), pp. 23-42.

${ }^{20}$ Mary Kaldor and Denisa Kostovicova, 'Global civil society, peacebuilding, and statebuilding', in Oliver P. Richmond and Gezim Visoka (eds), The Oxford Handbook of Peacebuilding, Statebuilding, and Peace Formation (Oxford, UK: Oxford University Press, 2021).

${ }^{21}$ My thanks to Holger Potzsch from the University of Tromso for pointing me to this concept.

${ }^{22}$ The use of the term 'architecture', though mentioned in academic circles previously, appeared to enter common UN parlance, albeit in a more limited way by 2016. It is mainly focused on prescriptive policies frameworks emanating from agencies like the Peacebuilding Commission. See General Assembly Resolution, A/RES/70/262, 'Review of the United Nations Peacebuilding Architecture', 12 May 2016, adopted by the General Assembly on 27 April 2016.

${ }^{23}$ Mary Kaldor, Old and New Wars (Cambridge, UK: Polity Press, 1999).

${ }^{24}$ Deleuze and Guattari, A Thousand Plateaus; Andrew Hurrell, On Global Order (Oxford, UK: Oxford University Press, 2008), p. 69.

${ }^{25}$ Immanuel Kant, Perpetual Peace: A Philosophical Sketch (Germany: F. Nicolovius, 1795); Daniele Archibugi, 'Models of international organization in perpetual peace projects', Review of International Studies, 18:4 (1992), pp. 295-317.
} 
practice has come into view in order to deal with different types of conflict: civil wars; revolutionary wars; colonial and imperial conflicts; wars over territory, power, and resources; industrialised conflicts over ideology as in the twentieth century; wars over ethnic identity and selfdetermination as seen regularly since the 1960s or after the end of the Cold War. The sheer variety and scale of such violence indicates points to the existence of a much more sophisticated peace architecture than generally thought. A significantly broader and multidisciplinary view illustrates this epistemological and methodological oversight.

Different critical understandings of this architecture emerge from different positionalities: the subaltern points to basic needs, identity, sustainability, and mobility: the state to its interests and communitarian ethics; the international to global norms, duties, and responsibilities in the light of global problems. Norms, institutions, law, across the international, the state, and civil society, reflect both the need to respond to wrongs as well as reflecting power. Inequalities of many (but not all) sorts are increasingly been seen as 'wrongs', meaning the nature of political legitimacy at the global level has now irrevocably changed. Similarly, matters of social, environmental, and intergenerational legitimacy have now made their appearance on the international scene. In this sense, legitimacy needs to be understood in broader, social and global, intergenerational terms, not just in terms of law, process, and efficiency. Legitimacy is related to the social provision of consent through consensual systems of political decision-making on a wider scale than ever before. ${ }^{26}$ It connects with the broader questions of sustainability raised by the problem of global justice.

\section{Six stages in the development of the IPA}

There are at least six overlapping stages of historical and theoretical development in the IPA. These need to be identified, theorised, and critiqued if a new stage is to either replace or rescue the overall system in the light of newer conflict dynamics in the twenty-first century. They comprise as follows:

(i) a geopolitical balance of power designed to deal with the clash of interests between elite-led industrialised states and empires;

(ii) a 'pluralist' Westphalian system of discrete sovereign states designed to deal with nationalism caused by stage (i) through the liberal democratic peace and a liberal cosmopolitan postwar architecture, designed to deal with the slow decolonisation of the imperial world and its systemic clashes, as well as nationalism and ethno-nationalism;

(iii) A Marxist-derived critique of both realist and liberal versions of peace designed to produce international equality and solidarity;

(iv) Liberal peacebuilding in its later iterations, informed by a postcolonial and hybrid, multilayered framework of international relations designed to expand rights while maintaining the previous layers of the international architecture; ${ }^{27}$

(v) Neoliberal statebuilding, and a reversion to securitisation and a focus on state security, complemented by global capital;

(vi) the newer 'digital' dynamics of international relations (as opposed to the analogue system of industrial modernity and the states system represented by i-iv), and which offers the potential of extending the agency of global civil society and further expanding rights, or constraining political claims through a form of digital governmentality.

\footnotetext{
${ }^{26}$ For more on these debates, see James Brasset and Eleni Tsingou, 'The politics of legitimate global governance', Review of International Political Economy, 18:1 (2011).

${ }^{27}$ Ibid., p. 2. See also Hedley Bull, The Anarchical Society (London, UK: Macmillan, 1977).
} 


\section{Stages one to four: From the balance of power to agenda for peace}

The sensitivity of the IPA to the vagaries of political hegemony and subaltern claims can be seen in its uncertain evolution. Stage one, relating to the balancing system of nineteenth-century geopolitics, allowed limited, Eurocentric progress to be made on the basis of a fragile, imperial balance of power, but one that was devoid of rights-based thinking being focus on the diplomatic balancing of interests:

the want of an habitual confidential and free intercourse between the Ministers of the Great Powers as a body; and that many pretensions might be modified, asperities removed, and the causes of irritation anticipated and met by bringing the respective parties into unrestricted communications common to them all, and embracing in confidential and united discussions all the great points in which they were severally interested. ${ }^{28}$

The Congress and Concert Systems aimed at maintain the European balance of power through elite diplomacy began to betray a concern with the broader stability and sustainability of an international order susceptible to constant wars, following the thought of Kant:

For these reasons there must be a league of a particular kind, which can be called a league of peace (foedus pacificum), and which would be distinguished from a treaty of peace (pactum pacis) by the fact that the latter terminates only one war, while the former seeks to make an end of all wars forever. ${ }^{29}$

Yet, such thinking, perhaps obvious, now was controversial as Palmerston famously noted in the House of Commons in 1848 (also reflecting contemporary cynicism about international cooperation and multilateralism):

We have no eternal allies, and we have no perpetual enemies. Our interests are eternal and perpetual, and those interests it is our duty to follow. When we find other countries marching in the same course, and pursuing the same objects as ourselves, we consider them as our friends, and we think for the moment that we are on the most cordial footing; when we find other countries that take a different view, and thwart us in the object we pursue, it is our duty to make allowance for the different manner in which they may follow out the same objects. ${ }^{30}$

This rather confused understanding of the pros and cons of international cooperation (because it was only worthwhile if there was a confluence of separate national interests) laid the basis for stage two, ${ }^{31}$ including the International Court of Justice's initiation at the 1899 Hague Conference and its implications for a wider acceptance of international law and new institutions to support order and progress in 'international society'. This also drew on the emergence of an interest in humanitarianism, with the foundation of the ICRC in the 1860s, as well as the problem of disarmament. Further steps were taken after the First World War with the liberal internationalist system that was built with the emergence of the League of Nations, following US President Wilson's argument that,

\footnotetext{
${ }^{28}$ 'The Earl of Ripon to the Marquess of Londonderry', 6 July 1839, cited in Charles K. Webster, The Foreign Policy of Lord Castlereagh (London, UK: Bell and Sons, 1931), p. 56.

${ }^{29}$ Immanuel Kant, 'Perpetual peace: A philosophical sketch', Perpetual Peace and Other Essays (Indianapolis, IN: Hackett Publishing Company, 2003 [orig. pub. 1795]).

${ }^{30}$ Viscount Palmerston, 'Speech to the House of Commons', Hansard, vol. 97, cc. 122 (1 March 1848).

${ }^{31}$ Robert Jervis, 'From balance to concert: A study of international security cooperation', in Kenneth A. Oye (ed.), Cooperation under Anarchy (Princeton, NJ: Princeton University Press, 1986), pp. 60-1; A. J. P. Taylor, Struggle for the Mastery of Europe, 1848-1918 (Oxford, UK: Oxford University Press, 1954).
} 
I can predict with absolute certainty that within another generation there will be another world war if the nations of the world do not concert the method by which to prevent it. ${ }^{32}$

Indicative of the difficulties in consolidating the second stage or layer of the IPA, the League of Nations was more or less immediately curtailed in 1919 given that the US did not join. Yet, the Locarno Agreements of 1925 appeared to confirm the progress that was being made, normalising relations in Europe (including the United Kingdom) with the Weimar Republic, and also reviving elements of the Concert system according to Georges-Henri Soutou: ${ }^{33}$

As early as 1921 the Europeans began to react against the far too abstract Wilsonian vision, realised that the League of Nations would not be very effective, and thought of reinstating, without acknowledging it, the Concert of Europe. This was achieved with the Locarno agreements, which reintroduced Germany into the Concert of Europe and which basically and beyond their actual content bestowed on France, Germany, Great Britain and Italy a leading role in the European system, as well as establishing among them a permanent forum for concerted meetings and action. It was actually a return to the former concert of the major powers, though one which of course took into account the new circumstances, at least as far as the implementation of 'collective security' was concerned. For some, for instance Aristide Briand, the Locarno system had to go beyond the return to the Concert of Europe and should promote the real political and economic organisation of the Continent, in order to balance both the Unites States and the Soviet Union. ${ }^{34}$

The Permanent Court of International Justice in 1920, the Kellog-Briand Pact to abolish war in 1928, as well as the attempt to codify international law at the Hague Codification Conference in 1930, were important steps but they all faced significant opposition. ${ }^{35}$

Yet, never before in history had there had never been so much progress in building an IPA than during the 1920s (this being perhaps faint and damning praise), culminating in slightly futile attempts to outlaw war:

The real struggle today, just as in the second quarter of the nineteenth century, is between a view of the world termed liberalism or radicalism, for which the primary object of government and of foreign policy is peace, freedom of trade and intercourse, and economic wealth and that other view, militarist or rather diplomatic, which thinks in terms of power, prestige, national or personal glory, the imposition of a culture and hereditary or racial prejudice. ${ }^{36}$

The growth of international law, the emergence of new forms of diplomacy, and growing multilateralism, were seen as markers consolidating peace architecture in the early twentieth century. ${ }^{37}$ They were to be brought together under an expanding institutional framework throughout the twentieth century. They were brought together according to an American-driven conglomeration of the development of liberal global order, vision for the state and the international system,

\footnotetext{
${ }^{32}$ President Woodrow Wilson, Speech in Omaha, Nebraska, 8 September 1919 in Ray Stannard Baker and William Edward Dodd (eds), The Public Papers of Woodrow Wilson: War and Peace: Presidential Messages, Addresses, and Public Papers (1917-1924) (New York, NY and London, UK: Harper, 1927), vol. 2, p. 36. For an invaluable resource, see 'Series 6, Peace Conference Documents, 1898-1921', available at: \{loc.gov/collections/woodrow-wilson-papers/about-this-collection\}.

${ }^{33}$ Baker and Dodd (eds), The Public Papers of Woodrow Wilson, p. 337.

${ }^{34}$ Ibid.

${ }^{35}$ Terry Nardin, 'The international legal order, 1919-2019', International Relations (2019), pp. 1-15 (p. 1).

${ }^{36}$ John Maynard Keynes, The Collected Writings of John Maynard Keynes, Volume 17: Activities, 1920-1922: Treaty Revision and Reconstruction (Cambridge, UK: Cambridge University Press, 2012), p. 370.

${ }^{37}$ Hans Morgenthau, 'Positivism, functionalism, and international law', American Journal of International Law, 34:2 (1940), pp. 260-84; Harold Nicolson, The Evolution of Diplomatic Method (London, UK: Constable, 1954).
} 
to cement the peace especially after decolonisation and again after the end of the Cold War. This 'liberal hegemony' was based to a large degree on popular acceptance of American exceptionalism after 1945, implying a mixture of realist and liberal approaches. It provided the basis for more significant activity after the end of the Second World War when the UN system, the Bretton Woods Institutions, the International Court of Justice, and much later, the International Criminal Court emerged. ${ }^{38}$ The UN Declaration of Human Rights in 1948 also gave rise to an expansionary dynamic, leading the Helsinki Accords in 1975 as a challenge to existing power relations. ${ }^{39}$ Of course, the 1945 postwar settlement represented perhaps one quarter of the world's population, depending on how one counts the proportion of signatory states (numbering 51) versus the world's population. It represented an elite and victor-based, fairly centralised consensus, such as was epistemologically and politically possible in its era, perhaps opening the way for a globally collaborative, social and relational, consensus. ${ }^{40}$ Thus, the international architecture as well as the state, by stage two of the IPA had been formed through war, the exercise of hegemony (including capital), particularly American, as well as social forces looking for recognition, emancipation, and rights over the longue durée. ${ }^{41}$

Part of this phase of the international architecture was based upon the moral purpose of the state being focused on augmenting individual potential, organised around liberal versions of sovereignty, legislative justice, and contractual international law, all within a multilateral umbrella supposed to support property rights within and of states. ${ }^{42}$

Stage three in the development of the modern IPA challenged liberal internationalism by underlining the very limited rights it propagated after 1919 and 1945. Stage three spanned the Marxist challenge to imperialism, capitalism, and liberalism, drawing on the revolutionary philosophies of the French and American Revolutions, the Soviet Union's vision of international peace, as well as the growing demands made by substantial numbers of newly decolonised states by the 1960s (including the Non-Aligned Movement this spurred). As Marx and Engels wrote:

The bourgeoisie has through its exploitation of the world market given a cosmopolitan character to production and consumption in every country ... In place of the old wants, satisfied by the production of the country, we find new wants, requiring for their satisfaction the products of distant lands and climes. In place of the old local and national seclusion and selfsufficiency, we have intercourse in every direction, universal inter-dependence of nations. And as in material, so also in intellectual production. The intellectual creations of individual nations become common property. National one-sidedness and narrow-mindedness become more and more impossible, and from the numerous national and local literatures, there arises a world literature. ${ }^{43}$

The very tense dialogue between stage two and stage three during the Cold War was also connected to decolonisation:

Never before in history has such a sweeping fervour for freedom expressed itself in great mass movements which are driving down the bastions of empire. This wind of change blowing through Africa, as I have said before, is no ordinary wind. It is a raging hurricane against which the old order cannot stand ... The great millions of Africa, and of Asia, have grown

\footnotetext{
${ }^{38}$ Nardin, 'The international legal order, 1919-2019', p. 2.

${ }^{39}$ Christian Reus-Smit, Individual Rights and the Making of the International System (Cambridge, UK: Cambridge University Press, 2013), p. 38.

${ }^{40}$ Matthew Desmond, 'Relational ethnography', Theory and Society, 43 (2014), pp. 547-79.

${ }^{41}$ Reus-Smit, Individual Rights and the Making of the International System, p. 2.

${ }^{42}$ Ibid., p. 7; John Gerard Ruggie, 'Multilateralism: The anatomy of an institution', in John Gerard Ruggie (ed.), Multilateralism Matters (New York, NY: Colombia University Press, 1993).

${ }^{43}$ Karl Marx and Friedrich Engels, The Communist Manifesto (London, UK: Penguin Classics, 2018 [orig. pub. 1848 ]), ch. 1.
} 
impatient of being hewers of wood and drawers of water, and are rebelling against the false belief that providence created some to be menials of others. Hence the twentieth century has become the century of colonial emancipation, the century of continuing revolution which must finally witness the total liberation of Africa from colonial rule and imperialist exploitation. $^{44}$

In 1964 the first UN Conference on Trade and Development (UNCTAD) was supposed to provide a response, repeated over the coming decade. ${ }^{45}$ The New International Economic Order proposals of 1973 were the heavily contested result. ${ }^{46} \mathrm{It}$,

[s]olemnly proclaim[ed] our united determination to work urgently for the Establishment of a New International Economic Order based on equity, sovereign equality, interdependence, common interest and cooperation among all States, irrespective of their economic and social systems which shall correct inequalities and redress existing injustices, make it possible to eliminate the widening gap between the developed and the developing countries and ensure steadily accelerating economic and social development and peace and justice for present and future generations ... ${ }^{47}$

US hegemony after 1945 helped make global relations and networks even denser than multilateralism suggested might be possible, expanding into civil society, science and technology, trade, law, conventions, and treaties. This was partly as a consequence of a transfer of American 'New Deal' thinking into the international sphere to create a stable institution national and international symmetry during the postwar era, according to Anne Marie Burley, ${ }^{48}$ plus the emergence of global civil society, much of it drawing on the stage three critique of stage two liberal internationalism. This dialogue provoked a substantial response that forced liberal internationalism to expand the peace framework that it offered for a transition towards a stage four framework, to redress the challenges raised by stage three, particularly relating to the continuation of colonialism, the circumscription of rights, and inequality. The beginnings of this process could be seen in the Helsinki Accords of 1975, which connected foreign policy, human rights, and the re-emergence of a European and potentially global order. This order capitalised on the evolving IPA. ${ }^{49}$

The Helsinki Accords, signed by the US, the Soviet Union, and most European states, linked state sovereignty, international and regional organisation, law, economic and social development with human rights to Western foreign policy. ${ }^{50}$ In this way, it provided a platform to bring the previous stages of the international architecture together, and to resolve some of its inconsistencies in the emerging stage four:

Recognizing the close link between peace and security in Europe and in the world as a whole and conscious of the need for each of them to make its contribution to the strengthening of

\footnotetext{
${ }^{44}$ Kwame Nkrumah, Africa Must Unite (London, UK: Heinemann, 1963).

${ }^{45}$ See also Lester B. Pearson, Partners in Development: Report of the Commission on International Development (New York, NY: United Nations, 1969).

${ }^{46}$ United Nations General Assembly, A/RES/S-6/3201, 'Declaration for the Establishment of a New International Economic Order', 1 May 1974.

${ }^{47}$ Ibid., preamble.

${ }^{48}$ Anne Marie Burley, 'Regulating the world', in Ruggie (ed.), Multilateralism Matters, pp. 125-56.

${ }^{49}$ For a brilliant exposition on the evolution of the European order, see Georges-Henri Soutou, 'Was there a European Order in the twentieth century? From the Concert of Europe to the end of the Cold War', Contemporary European History, 9:3 (2000), pp. 329-53.

${ }^{50}$ 'The Final Act of the Conference on Security and Cooperation in Europe', Helsinki, Finland, 1 August 1975.
} 
world peace and security and to the promotion of fundamental rights, economic and social progress and well-being for all peoples ... 51

Thus, stage four in the evolution of the IPA, drawing on a long tradition of the expansion of rights in the West, stabilised the existing layers of the architecture while enormously expanding its overall scope. It required a much higher set of standards than there might have been post-Second World War or in the early Cold War period. ${ }^{52}$ 'Agenda for Peace', published by the UN Secretary General in 1992 later captured some of these developments, in that it linked 'social progress and better standards of life in larger freedom' with prevention, peacekeeping, and peacebuilding was well as disarmament, drawing stages one to four together:

The sources of conflict and war are pervasive and deep. To reach them will require our utmost effort to enhance respect for human rights and fundamental freedoms, to promote sustainable economic and social development for wider prosperity, to alleviated distress and to curtail the existence and use of massively destructive weapons. ${ }^{53}$

R2P in 2005 was to become a logical outcome of this path, ${ }^{54}$ but it was not until 2018 that the UN issued a document that captured the full implications of these debates, including prevention, roots causes, expanded rights and a reconceptualised understanding of the state, inclusion and gender issues, and questions of social, economic, and global justice. There was a dawning realisation of the fuller dimensions of the IPA (UN documents were also now beginning to use the term 'peacebuilding architecture') required to deal with such a broad form of peace:

The scale and nature of the challenge of sustaining peace calls for closer strategic and operational partnerships among the United Nations, national Governments and other key stakeholders, including international, regional and subregional organizations, international financial institutions, civil society organizations, women's groups, youth organizations and the private sector, taking into account national priorities and policies. In today's complex world, those partnerships need to harness the energies of all sectors of society. The United Nations is one partner among others, and all partners need to come together in support of the efforts of Governments. ${ }^{55}$

The consequence was the creation of a relatively fairer, more stable, and prosperous state and international environment than so far ever seen in history, even when seen from the perspective of the subaltern. Indeed, the latter 'subaltern perspective' was to become even more significant as a result. Many of the ideas now widely accepted in stages two to four about the qualities of contemporary peace and order had first emerged in long series of anti-war and humanitarian, developmental, or standard-setting conferences, workshops, and conventions, often driven by civil

\footnotetext{
${ }^{51}$ Ibid., Preamble. See also chs I-IX.

${ }^{52}$ UN General Assembly, UN General Assembly Resolution 39/11, 'Right of peoples to peace', 1984; UN General Assembly and Security Council, Report of the UN Secretary General, A/72/707-S/2018/43, 'Peacebuilding and Sustaining Peace', 18 January 2018; UN General Assembly, 'International Covenant on Economic, Social and Cultural Rights (ECOSOC)', United Nations General Assembly Resolution 2200A (XXI), 16 December 1966: Stephanie DeGooyer et al. (eds), The Right to Have Rights (London, UK: Verso, 2018; Hannah Arendt, The Origins of Totalitarianism (New York, NY: Harcourt Brace, 1951); Cecilia Marcela Bailliet and Kjetil Mujezinovic Larsen, 'Introduction', Promoting Peace Through International Law (Oxford, UK: Oxford University Press, 2015), p. 9; Saskia Sassen, Territory, Authority, Rights (Princeton, NJ: Princeton University Press, 2006).

${ }^{53}$ Report of the Secretary-General, A/47/277-S/24111, 'An Agenda for Peace, Preventive Diplomacy, Peacemaking and Peace-Keeping', 17 June 1992, paras 3, 5.

${ }^{54}$ Alex Bellamy, 'The Responsibility to Protect turns ten', Ethics \& International Affairs, 29:2 (2015), pp. 161-85; Samuel Moyn, Not Enough: Human Rights in and Unequal World (Cambridge, MA: Belknap Harvard University Press, 2018).

${ }^{55}$ Report of the Secretary-General, A/72/707-S/2018/43, 'Peacebuilding and Sustaining Peace', 18 January 2018, para. 6.
} 
society actors spanning the nineteenth and twentieth centuries. Debate and pressure coalesced in the fourth layer of the IPA, including institutions such as the UN and its Agencies, NATO, the $\mathrm{EU}, \mathrm{AU}$, and other regional organisations, and the IFIs, the various international Courts and law, the donor systems, and an enormous range of NGOs. Even so, with the emergence of this layer progress was slow, heavily biased towards the Global North and to the remnants of imperial, sovereign, and authoritarian power. ${ }^{56}$

One can see, nonetheless, in this historical evolution the social construction of the international and the states system, partially aligned with social claims for security, rights, welfare, and justice. This process positioned a layer of liberal internationalism, democratisation and human rights, upon the nineteenth-century Balance of Power system, smoothing the way for the mitigation of imperial and state-centric war, as well as civil war. Though this process subaltern claims were represented in several waves ${ }^{57}$ through stages three and four to the degree allowed by by existing knowledge-power structures. Public goods developed to maintain peace and order through institutions, law, development, and legitimacy across local to global scales. Overall, stage four hybridised liberal and social welfarist versions of peace (such as the New Deal and Marshall Plan), as well as everyday and postcolonial versions ${ }^{58}$ (such as from the Non-Aligned Movement of the 1960s). Practical association was to follow function and form, eventually giving rise to a hybrid international society, much of which can now be historically observed. ${ }^{59}$

The alignment of social claims, the nature of the liberal state nested within liberalinternationalism and responsive to new rights claims (whether from labour, everyday, or postcolonial subjects) connected Thomas Hobbes's version of power ${ }^{60}$ with Max Weber's state ${ }^{61}$ and Hannah Arendt's notion of power in concert. ${ }^{62}$ It provided the framework for a substantial, postwar IPA, realised in a mix of geopolitics and liberal architecture, captured in the alignment and density of the IPA by stage four. It was more resilient in terms of its institutional and legal architecture and perhaps more responsive to subaltern claims.

Thus, the UN and Bretton Woods system, postwar, has overseen enormous, though unequal gains in security and human welfare, supported by NATO, regional organisations such as the EU, and an expanding list of donors, IFIs, INGOs, and NGOs, as well as many other related organisations. Yet this architecture is paradoxical and unstable, as any system of checks and balances tends to be (as it is under constant assault by powerful actors and interests). The state was seen as both the nexus for peace at the elite, diplomatic, and international level, as well as a key blockage for the kind of transformation necessary from the subject, individual, or subaltern

\footnotetext{
${ }^{56}$ Harold Nicolson, The Congress of Vienna: A Study in Allied Unity, 1812-1822 (London, UK: Constable \& Co., 1946); Henry A. Kissinger, A World Restored (London, UK: Weidenfeld \& Nicolson, 1957); Richard Little, 'Deconstructing the balance of power: Two traditions of thought', Review of International Studies, 15 (1989), pp. 87-100; Robert Jervis, 'From balance to concert: A study of international security cooperation', in Oye (ed.), Cooperation under Anarchy, pp. 60-1; John J. Mearsheimer, 'Bound to fail: The rise and fall of the liberal international order', International Security, 43:4 (2019), pp. 7-50; Nardin, 'The international legal order 1919-2019', pp. 1-15; Michael Doyle, Ways of War and Peace (New York, NY: Norton, 1997); John Gerard Ruggie, 'International regimes, transactions, and change: Embedded liberalism in the postwar economic order', International Organization, 36:2 (1982).

${ }^{57}$ Christian Reus-Smit, 'Struggles for individual rights and the expansion of the international system', International Organization, 65:2 (2011), pp. 207-42.

${ }^{58}$ See, for example, United Nations General Assembly, Resolution 2200A (XXI), 'The International Covenant on Civil and Political Rights', 16 December 1966; United Nations General Assembly A/RES/1514 (XV), 'Declaration on the Granting of Independence to Colonial Countries and Peoples', 14 December 1960, Art. 1.

${ }^{59}$ Terry Nardin, Law, Morality, and Relations of States (Princeton, NJ: Princeton University Press, 1983); Barry Buzan, 'International system to international society', International Organisation, 47:2 (1993), pp. 327-52.

${ }^{60}$ Thomas Hobbes, Leviathan (London, UK: Penguin, 1985 [orig. pub. 1651], p. 150.

${ }^{61}$ Max Weber, Economy and Society: An Outline of Interpretive Sociology (Berkley, CA: University of California Press, 1978 [orig. pub. 1922]), p. 53.

${ }^{62}$ Hannah Arendt, On Violence (New York, NY: Harcourt, Brace and World, 1951), p. 44.
} 
perspective. ${ }^{63}$ There was a similar pattern in relation to security and capital. Hence, the emergence of global institutions and international law, as well as democracy and human rights, as practical and normative elements of stage four. Transnational and local civil society saw itself as separate to the state and the international, and vital to the co-dependent development of both. ${ }^{64}$ The system is deeply rooted in the evolution of Western hegemony, just as in general institutions and power relations are deeply rooted in any society's past. ${ }^{65}$ Yet, it is also supposed to offer a Parsonian natural equilibrium ${ }^{66}$ under global governance and Western hegemony. Often a 'far from equilibria' situation was therefore put down to localised cultural, social, and historical deficiencies, meriting interventionary practices and systems for peace and development. ${ }^{67}$

\section{Internal contradictions, blockages, and counter-peace}

The internal tensions in the different elements of the IPA, its state-centric nature (drawing on nineteenth-century geopolitics) and elite political, economic, and social power, also means that the architecture has become more entrenched and difficult to reform as it expands. This is partly because it simultaneously provokes revanchist and counter-revolutionary forces associated with systems of geopolitics, nationalism, race, class, gender, and capital. Indeed, at every step along the way the development of peace and its related architecture has involved confronting and challenging existing vested power structures, residing in society, in empires and the state, the economy, the military, oligarchy, and ideology, among other locations of power.

The architecture's capacity is very much reactive - peace is formed after the event of war and conflict due to a mix of social and elite forces, and it is not able to anticipate the nature of future wars because of its limited capacities and the fact that new wars tend to shift character much more quickly (driven by elite power and resources). This is made worse by the opposition between social and elite approaches to peace, security, and order. The early 'hybrid peace' of empire and sovereignty has given way to other forms of hybrid peace, increasingly associated with a state-mediated version of local and international politics (mediated by custom, identity, liberalism, neoliberalism, and the influences of global networks). However, this path has not been smooth, because of Western suspicion about the counter-discourses of the development world, especially after the Bandung Conference after $1955 .{ }^{68}$ The West saw claims for decolonial demands for liberty and global justice as producing revolutionary resistance to its dominance at a risky moment in the Cold War, rather than developing a more appropriate response to everexpanding rights claims as everyday subaltern political claims became clearer in international politics. Elite power and social actors have both been instrumental in such mediation over history, indicating how the evolution of the IPA has been inevitably entangled with its nemesis: a counterpeace architecture.

The IPA has thus suffered something of a 'death of a thousand cuts', on critical and conservative, 'counter revolutionary' fronts. ${ }^{69}$ This has partly been because of the challenge of inconsistency in maintaining a common, normative order (see the cases of Syria since 2011 and Rwanda in 1994 versus say Kosovo and Bosnia in the late 1990s), and partly because of what Michael Mann

\footnotetext{
${ }^{63}$ Immanuel Wallerstein, 'New revolts against the system', New Left Review, 18 (2002), available at: \{http://www.newleftreview.net/NLR25202.shtml\}.

${ }^{64}$ Mikka Pyykkonen, 'Liberalism, governmentality and counter-conduct', Foucault Studies, 20 (December 2015), p. 11; Margaret E. Keck and Kathryn Sikkink, Activists Without Borders (New York, NY: Cornell University Press, 1998).

${ }^{65}$ Daron Acemoglu and James A. Robinson, Why Nations Fail (London, UK: Profile, 2012), p. 44.

${ }^{66}$ Michael Reed and David L. Harvey, 'The new science and the old: Complexity and realism in the social sciences', Journal for the Theory of Social Behaviour, 22:4 (1992), p. 365.

${ }^{67}$ Ibid., p. 366.

${ }^{68}$ Richard Devetak, Tim Dunne, and Ririn Tri Nurhayati, 'Bandung 60 years on: Revolt and resilience in international society', Australian Journal of International Affairs (April 2016).

${ }^{69}$ Barry R. Posen, Restraint (Ithaca, NY: Cornell University Press, 2014), p. 175.
} 
called the challenge of the autonomous power of the state: the way in which it uses infrastructural power to divide and penetrate civil society, supporting the territorial centralisation of state power rather than the expansion of human rights. ${ }^{70}$ This has in turn been altered by neoliberalism and the current digital shift and their influence on the overall architecture. The relationship between postcolonial sovereignty and human rights, as well as the requirement of a state to enforce human rights, has been uneasy, to say the least. Indeed, as Samuel Huntington argued in the 1960s, political systems decay and break down when they are no longer able to meet evolving or emerging challenges. ${ }^{71}$ The authoritarian impulse is never far away under such circumstances, especially in view of the fact that emancipation, justice, and rights claims are an inevitable challenge to entrenched and failing power structures, which will resist concessions. ${ }^{72}$ Even now the numbers of democratic states appear to be declining or shifting towards authoritarian capitalism during and after war. Thus, the IPA is evolving precisely because it is entangled with the very forces of war and violence it was supposed to tame, partly because it is loaded towards hegemony rather than expanding rights frameworks. A counter-peace framework is also emerging which opposes its influence in international relations but also requires a limited IPA at strategic points in time (to reassess, recuperate, and reorganise).

The example of peacebuilding in Bosnia-Herzegovina is illustrative of stage four and its limitations. The dominant process over the period since the 1995 Dayton Peace accords has not merely been UN, OSCE, and EU supported peacebuilding and the peace process, ${ }^{73}$ although some progress has been made. ${ }^{74}$ Dominant power structures have revived. These have blocked reforms, stopped the expansion of civil society, and pushed back the rule of law. They have also limited the scope for action of the Office of the High Representative, making it very difficult to move beyond the fragile Dayton Agreement. ${ }^{75}$ Neither the EU or the US have been able build their version of peace, and the UN has been similarly ineffective in the face of local and regional politics. ${ }^{76}$ Bosnia's progress towards EU accession has stalled, as has civil society's localisation and global outreach. ${ }^{77}$ The offending power structures are based upon the rents political elites receive from ethnic conflict and tension, ethno-nationalism, territorialism and boundaries, secessionism, militarism, as well as the gains made from unregulated capital. ${ }^{78}$ The peacebuilding elements of the Dayton Peace Agreement were merely contained in an Annex, after all. ${ }^{79}$

The UN, EU, and other organisations appeared to be trying to build a more sophisticated, liberal peace, but in the end have supported stabilisation type policies given the strength of localised power relations, and the limited capacity of liberal peacebuilding to represent social and cultural

\footnotetext{
${ }^{70}$ Michael Mann, 'The autonomous power of the state: Its origins, mechanisms, and results', Archives européenes de sociologie, 25 (1984), pp. 185-213.

${ }^{71}$ Samuel Huntington, Political Order in Changing Societies (New Haven, CT and London, UK: Yale University Press, 1968).

${ }^{72}$ Michael Pugh, 'The political economy of peacebuilding: A critical theory perspective', International Journal of Peace Studies, 10:2 (2005), pp. 23-42.

${ }^{73}$ Richard Caplan, 'Assessing the Dayton Accord: The structural weaknesses of the general framework agreement for peace in Bosnia and Herzegovina', Diplomacy and Statecraft, 11:2 (2000), pp. 213-32; David Chandler, Bosnia: Faking Democracy After Dayton (London, UK: Pluto Press, 2000); Susan L. Woodward, 'Implementing peace in Bosnia and Herzegovina: A post-Dayton Primer and Memorandum of Warning', Foreign Policy Studies Program (Brookings Institute, 1996).

${ }^{74}$ See, for example, 'Council of Europe Action Plan for Bosnia and Herzegovina 2018-2021 Progress Review Report (June 2018-March 2020)’ (27 May 2020), available at: \{https://search.coe.int/cm/Pages/result_details.aspx?ObjectId=09000016809e7f1c\}; Author's interview with confidential source, Office of the High Representative, Sarajevo, 9 August 2017.

${ }^{75}$ Ibid.

${ }^{76}$ Ibid.

${ }^{77}$ Ibid.

${ }^{78}$ Roberto Belloni, The Rise and Fall of Peacebuilding in the Balkans (London: Palgrave, 2020), p. 81.

${ }^{79}$ General Assemby Resolution A/50/79C and Security Council Resolution, S/1995/999, 'General Framework Agreement for Peace in Bosnia and Herzegovina (Dayton Agreement)', 30 November 1995.
} 
practices in the Balkans, or repair the war economy. ${ }^{80}$ The peacebuilding process enabled continuity in public office, institutions, clientelistic elites, who subverted democracy, rights, development, and civil society in their interests in a complex double movement. ${ }^{81}$ This made international actors think they had control while devolving power on a growing basis to local actors and civil society. This produced dependence and a negative peace based upon ethnonationalism, power sharing, and neoliberalism. ${ }^{82}$ It allowed powerful elites to step into the vast areas of the political economy where civil society and international actors had limited traction. By 2017, senior international actors thought 'local ownership' strategies had failed. ${ }^{83}$ Civil society began to develop a familiar critique based about class, human rights, and social democracy, one which was not audible to the international community, thus replaying important elements of Yugoslavian history but without the resolution Tito once achieved or the more recent focus on democracy or human rights. These dynamics offer an insight into the counter-peace framework:

Peacebuilding become increasingly hijacked by local gate-keepers bent on continuing the exploitation of economic and political opportunities afforded to them by permissive neoliberal economic policies ... they achieved mostly superficial changes that did not impact [upon] either the deeper societal structures or the domestic elites' power base. ${ }^{84}$

In addition, the state's resources were being plundered within the same framework, as well as its labour being appropriated by multinational interests, leading to social unrest and the formation of attempts to govern from below with limited results. ${ }^{85}$ Yet, it is still common to hear from international actors that more privatisation is required, even though this has tended to hand power to various oligarchs. ${ }^{86}$ These counter-peace dynamics challenged and neutralised the already weak liberal peacebuilding framework of the 1990s. Ever since they have undermined its social, political, economic, and legal frameworks, as well as attempts at regional and international governance through the EU, OSCE, UN, and donor system.

International actors themselves were also very divided, both within and outside the Western alliance framework, by interests, normative and practical approaches to maintain a coherent position. ${ }^{87}$ Counter-peace and blockages are also useful to them for strategic reasons. The UN created a framework for statebuilding and peacebuilding that had little localised, social, or elite legitimacy. The EU has been suffering from 'accession fatigue' in the region, and Republika Srpska would prefer a regional alliance with Serbia and Russia. Thus, geopolitics is rearing its head along with ethno-nationalism once again. ${ }^{88}$ Space has been created for both by the deadlock within political community over state reform and international support. Thus, taking a counter-peace perspective underlines how stage one of the IPA has not solved geopolitics in the region: and stage two is deadlocked because democracy is in stalemate, partly because of geopolitics but also because of the failure of development policies. The expansion of rights has been uncertain (as the civil protests in $\mathrm{BiH}$ of 2014 illustrated) and cannot work without the other layers operating too, especially through external support. This has meant that reconciliation has been undermined and replaced by entrenchment on a mass scale.

\footnotetext{
${ }^{80}$ Belloni, The Rise and Fall of Peacebuilding in the Balkans, p. 235; Michael Pugh, 'The political economy of peacebuilding: A critical theory perspective', International Journal of Peace Studies, 10:2 (2005), pp. 23-42.

${ }^{81}$ Belloni, The Rise and Fall of Peacebuilding in the Balkans, p. 81.

${ }^{82}$ Ibid., pp. 82, 204.

${ }^{83}$ Author's interview with confidential source, Office of the High Representative, Sarajevo, 9 August 2017.

${ }^{84}$ Belloni, The Rise and Fall of Peacebuilding in the Balkans, p. 231.

${ }^{85}$ Jasmin Ramovic and Roberto Belloni, 'Elite and everyday social contracts in Bosnia and Herzegovina: Pathways to forging a national social contract?', Journal of Intervention and Statebuilding (2019); Jasmin Ramovic, 'Looking into the past to see the future? Lessons learned from self-management for economies in post-conflict societies of the former Yugoslavia', Civil Wars, 20:2 (2018), pp. 171-92.

${ }^{86}$ Author's interview with confidential source, Office of the High Representative, Sarajevo, 9 August 2017.

${ }^{87}$ Ibid.

${ }^{88}$ Ibid.
} 


\section{The emergence of stage five}

The more the complexity of the IPA, the more it risked failure as it challenged the geopolitical power structures of stages one in the IPA, and raised expectations of expanded rights and intervention to promote political order in stages two to four. The commensurate and receding gradations of sovereignty and agency from north to south have long been noted ${ }^{89}$ This undermined the complex processes of security, institutionalisation, rights, and development, effectively undermining common projects and misallocating 'surpluses' in the evolving architecture. ${ }^{90}$ This meant that by stage four the IPA ran on a very low margin of reserve capacity under the conditions of global capitalism and the neoliberal state model. Its surpluses were run down, blocking reform (as discussions of UN reform have long illustrated). ${ }^{91}$ Intervention (broadly defined in the form of peacekeeping, mediation, peacebuilding, and development), the reform of the state, and civil peace formation processes were reactive rather than proactive processes. They operated within the framework of preserving states and only the most basic of rights, underpinned by the avoidance of historical and distributive questions of justice. ${ }^{92}$

Since the neoliberal shifts from the 1970s, the Global North's hegemonic states along with authoritarian states in the south slowly retreated from the expansion of rights and equality as a political solution for war and violence. To some degree progress already made has helped mitigate the historical cycle of war, occupation, colonisation, tribute, and trusteeship. Yet, systems of war and violence became increasingly complex and opaque (even despite their growing academic exploration). They were no longer analytically legible through the state or a liberal international states system. In parallel, the growth of complex systems of governance designed to prevent local, state, and international conflict by redressing social, economic, and territorial grievances, was now consuming vast amounts of energy, resources, and political will. Much of the peace work of the last two decades has been status-quo oriented, as 'stabilisation' approaches appeared to replace peacekeeping and peacebuilding (as in Syria since 2011) ${ }^{93}$ A loss of energy and political will due to a decline in marginal returns for the liberal peace and neoliberal statebuilding pointed to a loss of legitimacy and a concurrent growth of complexity (with little in the way of new technologies and new sources of energy for peacemaking emerging to save the overall IPA). ${ }^{94}$

The 2000s saw the rise of an authoritarian and neoliberal peace in stage five of the IPA. It was focused on statebuilding, regional security, supported by global capital, in the hope that 'stabilisation' would buttress the development of legitimate authority in conflict-affected environments like Afghanistan and Iraq:

The long-term vision for international engagement in fragile states is to help national reformers to build effective, legitimate, and resilient state institutions, capable of engaging productively with their people to promote sustained development. ${ }^{95}$

It was often supported implicitly by the West for reasons of security and a lack of political will, or by the newer powers such as China, for reasons of trade and regional

\footnotetext{
${ }^{89}$ For a recent iteration, see John Hobson, The Eurocentric Conception of World Politics (Cambridge, UK: Cambridge University Press, 2012), p. 19.

${ }^{90}$ Tainter, The Collapse of Complex Societies, pp. 37, 190.

${ }^{91}$ Ibid., p. 60, 122; Simon Chesterman, 'The Outlook for UN Reform', Public Law Research Paper No. 11-55 (New York University School of Law, 12 July 2011), available at: \{https://ssrn.com/abstract=1885229 or http://dx.doi.org/10.2139/ssrn. $1885229\}$.

${ }^{92}$ Cohen, Globalisation and Sovereignty, pp. 159-222.

${ }^{93}$ Frances Z. Brown, 'Dilemmas of Stabilization Assistance: The Case of Syria', Carnegie Endoment for International Peace, available at: \{https://carnegieendowment.org/2018/10/26/dilemmas-of-stabilization-assistance-case-of-syria-pub$77574\}$ accessed 26 October 2018.

${ }^{94}$ Tainter, The Collapse of Complex Societies, p. 116.

${ }^{95}$ OECD-DAC, 'Principles for Good International Engagement in Fragile States and Situations' (April 2007), p. 1, available at: \{www.oecd.org>dac`conflict-fragility-resilience $>$ docs $\}$.
} 
influence. This process has been careless with both the local and global legitimacy of the existing IPA:

To quote Condoleezza Rice, then US National Security Advisor and Bush confidante: 'The concept was that we would defeat the army, but the institutions would hold, everything from ministries to police forces'... The unpredicted collapse of the state in the immediate aftermath of the seizure of Baghdad dramatically changed the nature and extent of the USA's involvement in Iraq ... Attempts at rebuilding the state in Iraq, not the original plan for limited reform, have proved to be far more complex, requiring much greater expertise and resources than anyone in the US government had anticipated or planned for. ${ }^{96}$

What emerged with stage five was an unstable version of the victor's peace, mirrored by the case in Sri Lanka after the collapse of the Norwegian backed peace process in 2002 and the rise of President Rajapaksa's nationalist and militarist regime as well as his ongoing incursions into the state while in political opposition. ${ }^{97}$ At the far end of the scale it gave rise to the tragic case of the Syrian war since 2011.

\section{Growing instabilities in the overall IPA}

The contradictions of the Global North's stage four and stage five frameworks in the IPA soon emerged between territoriality, borders, rights, and capitalism, as well as its paternalistic and ideological overtones, which have undermined its global legitimacy and progressive goals. Its capacity to build legitimacy and oversee the handover of power peacefully through elections was not in doubt but the political agenda that dominated reform templates in conflict affected societies have been powerfully challenged. To quote Jurgen Habermas, 'One size fits all fits no one.' ${ }^{\text {' }}$ Rather than an alignment of power, the state, and civil society through multilateralism in stage four, global governance in stage five turned to neoliberal, technological, and military hegemony rather than human rights or social justice ${ }^{99}$ (not to mention global justice). This has undermined the entire architecture as well as the micro-processes within it (for example, peacekeeping, peacebuilding, and mediation). Indeed, global governance diffuses and fragments the power needed to achieve rights and social justice from a subaltern perspective.

Immanuel Wallerstein, via his core-periphery perspective, argued that the world faced a structural crisis as a consequence of such tensions. ${ }^{100}$ War is now experienced as a piecemeal, disaggregated, multiple phenomena: from the complex, regional, and civil war in Syria, guerilla warfare as recently ended in Colombia, to urban violence as in Latin America in particular, and the environmental and structural violence that global capital enables in its 'misallocation of resources' towards multinational, oligarchical, and authoritarian actors as in the MENA region or sub-Saharan Africa (say in the DRC) or Southeast Asia (as perhaps in Cambodia). This echoes the old problem that transformative movements and processes often end up close to the stance they were trying to redress (often because power is persuasive and seductive, with an obvious advantage), as well as the old issue of whether transformation, reform, and emancipation are possible from within the status quo, or only from the outside (that is, a revolutionary or radical social movement aimed at broader forms of global justice). Empirically, as Wallerstein pointed out,

\footnotetext{
${ }^{96}$ Toby Dodge, 'Iraq: The contradictions of exogenous state-building in historical perspective', Third World Quarterly, 27:1, 'From Nation-Building to State-Building' (2006), pp. 188-9.

${ }^{97}$ Author's interview with Jehan Perera, Director of National Peace Council, Colombo, 17 November 2015; Jehan Perera, Seminar, Manchester University, 13 December 2018.

${ }^{98}$ Jurgen Habermas, The Lure of Technocracy (Cambridge, UK: Polity, 2015), pp. 32, 47-9.

${ }^{99}$ See, for example, Tom Pegram and Michele Acuto, 'Introduction: Global governance in the interregnum', Millennium, 43:2 (2015), p. 585.

${ }^{100}$ Wallerstein, 'New revolts against the system', pp. 3, 5 .
} 
there were periods in the twentieth century when radical movements were in the ascendancy, but they did not manage to directly transform the world. ${ }^{101}$ Furthermore, more recent discursive theories discourage deep analysis of contemporary structural problems, focusing attention on more indirect social and communicative dynamics instead, which identify but do not redress injustice in the short to medium term at least. Structural analyses, on the other hand, have since Marx suggested that power and networked solidarity across the global scale was needed to mitigate threats to social peace and order.

For example, mediation, peacekeeping, and peace processes were reserved from the 1950s for the most egregious threats to the Cold War balance, but with the arrival of peacebuilding doctrine in the 1990s broader strategies were expected deal with deeper instabilities and injustices by expanding the liberal international order. However, the IPA by the 1990s was under great pressure to expand further to accommodate not just postcolonial conflicts, but also post-Soviet, and developmental conflicts. This meant that substantial elements of the IPA (for example, stage one to five preserved the northern dominated hierarchy) were increasingly opposed to the structural changed required to stabilise the international order and in tension with other elements such as the expansion of rights and concerns with justice (in stages three and four). This shift towards more decentred forms of globalism, pluralism, and localism, has had the unintended consequence of fragmenting the power, consensus, and agency needed to make peace. It is dependent upon ever broader tools and programmes of intervention. ${ }^{102}$ Many of these interventions govern consequences rather than causes, ${ }^{103}$ disguising the relationship between peace, power, and knowledge, and narrowing emancipatory practices to a minimalist level. As David Chandler has argued, the focus of intervention has moved from the causes of conflict (if it ever was focused on causes) to managing its effects. ${ }^{104}$

\section{Potential for the architecture: Stage six}

We cannot continue to work with $20^{\text {th }}$ century tools in the $21^{\text {st }}$ century. ${ }^{105}$

Kalevi Holsti offered an early impression of the need for multiple elements necessary for a viable peace system, including legitimate authority and governance, the capacity for peaceful change and conflict resolution. ${ }^{106}$ This has been increasingly reflected over time by the development of the $\mathrm{UN}$, donor, regional, and INGO system, international law, and expanded notions of rights. These have been crucial in the reconstitution of sustainable political order as it developed across layers of the IPA. ${ }^{107}$ Stage six of the architecture inevitably requires constant intellectual innovation, and material and geopolitical investment, as well as support for its rights expansion and transversal dynamics. As a global framework its global legitimacy is paramount: yet the 'undermining of the landmarks of modernization' is well underway. ${ }^{108}$ As Ulrich Beck argued so cogently, the international peace 'project' (or in his case the European peace project) needs to address the problem of how the architecture might be improved, drawing on what has been

\footnotetext{
${ }^{101}$ Ibid., p. 5 .

${ }^{102}$ Barry Buzan and George Lawson, The Global Transformation (Cambridge, UK: Cambridge University Press, 2015), p. 273

${ }^{103}$ This can be seen in numerous Research Council calls in the UK, as well as in a more general appeal for more applied research to be carried out using large datasets or new technologies.

${ }^{104}$ David Chandler, 'Reconceptualising international intervention: Statebuilding, "organic processes" and the limits of causal knowledge', Journal of Intervention and Statebuilding, 9:1 (2015).

${ }^{105}$ Herve Ladsous, Head of UN Peacekeeping, 'UN peacekeeping chief wants more drones', Al Jazeera (30 May 2014).

${ }^{106}$ Kalevi Holsti, Peace and War (Cambridge, UK: Cambridge University Press, 1991).

${ }^{107}$ Glenn M. Scwartz and John J. Nichols (eds), 'From collapse to regeneration', After Collapse: The Regeneration of Complex Societies (Tuscon, AZ: Arizona University Press, 2006), p. 8.

${ }^{108}$ Philip G. Cerny and Alex Prichard, 'The new anarchy: Globalisation and fragmentation in world politics', Journal of International Political Theory (October 2017).
} 
learned about the previous layers of the IPA. ${ }^{109}$ Perfecting the state now means expanding rights into temporal, environmental, and thus material areas to reflect subaltern claims. Democratising the international adds a concern with global inequalities and long-term sustainability, as raised by global civil society networks, as well as emancipatory global governance linked to global justice. Such a trajectory challenges geopolitics and geo-economics, excavates socio and anthropocentric versions of politics, and points to deep relationality across societies and the deep structures of the environment or commons. ${ }^{110}$

The social content of security, peace, rights, development, and order is foregrounded under these new structural conditions, rather than the empirical nature of the state, security, or economy, these now being components of a twenty-first century peace rather than its main priority as in the twentieth century. This reaffirms the local, social, and micro 'turns' that have recently gained ground, ${ }^{111}$ and are actually extensions of a long process of 'rights-seeking' across cultural, political, social, and economic terrains by populations around the world since the nineteenth century. This process, associated with the emergence and expansion of human rights, has led to historical structural change which in the recent 'decolonial epoch' means pushing beyond a core-periphery neocolonial or economic system, ${ }^{112}$ which were the dominant systems of the twentieth century.

Thus, drawing on the lessons of the evolution of the IPA so far, a science-led version of peacebuilding in a new stage six framework would deal with underlying power structures, represent social practices and build transversal, trans-scalar, and transnational political, institutional, legal, and bureaucratic frameworks. This would advance the previous state-centric, multilateral, international law and trade networks, as well as deepening global civil society, which emerged from the debates between science and politics/IR in the previous stages.

Firstly, it requires a viable international political architecture with the capacity to manage and resolve the conflicts of the day. It would be made up over the long term of multiple, sedimental layers of actors, dynamics, laws, institutions, and networks, which firstly, neutralise each era's war and conflict dynamics. Secondly, these layers should maintain themselves in relation to the other layers of the architecture, providing stability in the long term. Thirdly, taken all together they must be sufficiently stable to offer a platform for the expansion of future layers of the architecture as new conflict types emerge.

This social construction rests from local to global scale to some degree on an Aristotelian realisation that political community from the local to the global is an association ${ }^{113}$ or many relational entanglements. It is made up of cooperative relationships aimed at justice, security, and rights, as well as emancipation and equality. It does not merely represent a Hobbesian contracting out of self-preservation through a social contract to a Leviathan state (and international hegemon), or a Lockean conversion of natural rights into civil rights under the paternalistic state (or international hegemony). This perspective brings together realist, liberal, constructivist, and critical views of the history of IR, connecting governance and hegemony, order formation, and the foundations of international order. ${ }^{114}$ In indicates that the international architecture has been formed through two processes, one a linear process of liberal institution and constitution building, perhaps leading to some sort of global federation, and secondly this has been brought

\footnotetext{
${ }^{109}$ Ulrich Beck, German Europe (Cambridge, UK: Polity Press, 2013), p. 26.

${ }^{110}$ William E. Connolly, Facing the Planetary (Durham, NC: Duke University Press, 2016), p. 121.

${ }^{111}$ Ty Solomon and Brent J. Steele, 'Micro-moves in International Relations theory', European Journal of International Relations, 23:2 (2016).

${ }^{112} \mathrm{~N}$. Dhawan, 'Affirmative sabotage of the master's tools: The paradox of post-colonial enlightenment', Decolonising Enlightenment: Transitional Justice, Human Rights, and Democracy in a Postcolonial World (Berlin: Barbara Budrich, 2014), p. 70; Immanuel Wallerstein, 'New revolts against the system', New Left Review, 18 (2002), available at: \{http:// www.newleftreview.net/NLR25202.shtml\}.

${ }^{113}$ Aristotle, Politics, Book 1, 1, p. 54.

${ }^{114}$ John Gerard Ikenberry (ed.), 'Introduction', Power, Order, and Change in World Politics (Cambridge, UK: Cambridge University Press, 2013), p. 3.
} 
partly by the micro-powers that actualise subaltern political claims, which is a far more networked, transversal process, leading to more decentralised systems of governance.

If such a path were to come to fruition, this would point to a very complex forms of peace praxis. Peacekeeping, mediation, peacebuilding, development and statebuilding, as well as global civil society and multilateral actors would connect peace praxis with reconciliation, equality, justice and sustainability, across issue areas, networks, and scales. This new layer has so far mainly been prepared in critical work on peace and conflict in theory but is also reflected in the UN's Sustaining Peace Agenda. ${ }^{115}$ It is also shaped by practices, emotions, and everyday spatial, historical, understandings of complex agency, which is mobile and networked. ${ }^{116}$ It is transversal, transscalar, post-nationalist, and concerned with long-term sustainability, foreshadowing complex frameworks of global justice. This means the further expansion and enhancement of rights in the light of new structural global conditions, subjectivity, and political claims, and a new and broader understanding of legitimacy that has emerged especially at the social level, if not at the international or state levels. ${ }^{117}$ Mobility, relationality, and networks (assemblages which cannot be defined solely as local or global $)^{118}$ underpin this shift through which critical agency at the social level engages with power structures at the state or global levels while doing their utmost to avoid domination. ${ }^{119}$ The former aims to provide a relational and pluralist ontology for IR that is far more stable and sustainable than the older notions of the territorial sovereignty or cosmopolitan/Eurocentric norms, state encompassment, and vertical hierarchy. ${ }^{120}$

\section{An alternative path: Stage six as digital governmentality}

More negative alternatives are also on the horizon (though it is too early to make a decisive characterisation), given the fragility and underlying contradictions of the previous layers of the IPA. The mounting contradictions of the previous layers, its blockages, and failures have meant that stage six does not merely represent a new layer of the IPA that builds on the previous layers heralding a peace with global justice. Instead, it is contested and thus has come into being as the first layer that is clearly bifurcated, limiting its capacity to stabilise the existing layers of the IPA or deal with the newer dynamics driving war and conflict.

This strand of layer six include the possibilities of a 'pax technica': ${ }^{121}$ a hybrid of neoliberalism, new technologies of power, extending many of the older, predatory patterns of elite political power, which might be termed 'digital governmentality'. A turn to digital and AI technologies to overcome the complexity of the IPA's implications for peace, actually anchors this version of stage six in refreshed variants of stages one and five (geopolitics and statebuilding/stabilisation). It highlights recent tendencies for deliberalisation following authoritarian instincts, reinforcing the hierarchical international architecture of relatively exclusive territorial states. ${ }^{122}$ This

\footnotetext{
${ }^{115}$ Report of the Secretary General, para. 6.

${ }^{116}$ Henri Lefebvre, The Critique of Everyday Life, Volume 1, trans. John Moore trans (London, UK: Verso, 1991 [orig. pub. 1947]).

${ }^{117}$ Drawing on Hannah Arendt, The Origins of Totalitarianism (New York, NY: Harcourt Brace, 1951); DeGooyer et al. (eds), The Right to Have Rights, p. 4.

${ }^{118}$ Sassen, Territory, Authority, Rights.

${ }^{119}$ See, for example, Michel Foucault, Power/Knowledge: Selected Interviews and Other Writings, 1972-1977 (New York, NY: Pantheon Books, 1980).

${ }^{120}$ James Ferguson and Akhil Gupta, 'Spatializing states: Towards an ethnography of neoliberal governmentality', American Ethnologist, 29:4 (2008), p. 988.

${ }^{121}$ For one such argument, see Philip N Howard, Pax Technica (New Haven, CT: Yale University Press, 2015), p.xix. Pax technica is a new empire drawing on a technical rationality that emerges from networked devices, networked power, and networked society. It undermines the states system and democracy, as well as the concept of the state as a self-determining unit, as such concepts are transcended by a range of networks. Ibid., pp. xx, 1, 33-5. See also Herbert Marcuse, One Dimensional Man (London, UK: Sphere Books, 1968), p. 25, cited in Mark Duffield, Post-Humanitarianism (Cambridge, UK: Cambridge, Polity), p. 41.

${ }^{122}$ As incidentally illustrated by UNDP's Human Development Index.
} 
rejects Karl Polyani's argument that redistribution (and so justice) is the basic function of political order $^{123}$ and instead deploys new tools to maintain political and economic inequality and injustice to buttress public reason and existing power relations through the search for:

an experimental tool in a terrestrial struggle to covert history and politics in to information and data. $^{124}$

There is a reactionary, 'counter-revolutionary' tendency inherent in this new layer, through which traditional power relations attempt to reassert themselves, rejecting or diluting expanded rights and scientific claims about sustainability and global justice. Older concerns with land and territory, as well as material resources, still represent the base of modern direct, structural and governmental power. This means that the development of stage six towards justice and sustainability would be almost immediately blocked by digital governmentality, which deflects stage six and allows stage one to re-emerge, drawing on the blockages and the counter-peace frameworks that began to re-emerge in stages four and five.

\section{Conclusion}

The IPA offers different and often contradictory sediments or layers of contemporary IRbetween geopolitics, capitalism, law, rights and norms, cooperative institutional development, and the critical search for a deeper justice and sustainability. Firstly, the history of global power relations and hegemony has produced an informal and public, political, and economic architecture, which might be equated with the evolution of negative peace in international relations. The victor's peace, the liberal peace, and the neoliberal peace, have been recent historical forms under European and US trusteeship and tutelage, brought together in a second layer, the liberal peace. Thirdly, this provided a platform for the 'rights of the governed' to expand, as the subject was valourised and protected, both supported and restrained by the state and international law as in stages three and four. Each new step opened up further possibilities in view of the broad goals of emancipatory peace thinking. ${ }^{125}$ Finally, there are also emerging neoliberal retrenchments, digital, and technological forms of conflict, which shape stages five and six. They need a 'peace' response and a new layer of the IPA to respond to them.

The direction of the development of the concept of peace in broad terms suggests a journey from the victor's peace (imperialism); a social peace (based upon political, social, a and economic rights); the liberal peace (liberal democratic states, rights, trade, and international law and organisation); a neoliberal peace (states security and global trade), towards peace with global justice. The latter, as reflected in the recent UN SDGs and Sustaining Peace agenda, connects peace with environmental sustainability, gender, distributive, and historical justice, suggesting an agonistic yet consensus-based form. This could be described as new framing of peace related to global justice, beyond state-centric and liberal public reason and in a postcolonial framework.

The palimpsest of the IPA identified in this article comprises two processes: a linear (namely, problem-solving driven) and a rhizomatic (critical and rights driven) development of different approaches to developing peace, security, and order. It illustrates how the whole architecture is to a greater or less degree bifurcated - more obviously with stage six - in the context of the 'fragmegration' of the international system. This mirrors the dual Foucauldian insights into firstly the production of governmentality and biopower through the development of entrenched power relations that normalise situations that are unjust, unequal, unsustainable, and dangerous, even while

\footnotetext{
${ }^{123}$ Karl Polanyi, Conrad M. Arensberg, and Harry W. Pearson (eds), Trade and Market in the Early Empires: Economies in History and Theory (New York, NY: Free Press, 1957).

${ }^{124}$ Mark Duffield, Post-Humanitarianism (Cambridge, UK: Polity, 2019), pp. 153-4.

${ }^{125}$ Ben Goulder, Foucault and the Politics of Rights (New York, NY: Stanford University Press, 2015), pp. 16, 20.
} 
Layers of Peace Architecture

\section{Conflict Type}

Layer 6

Inequality, lack of justice, unsustainability

(Stage: Twenty-first century digital peace/ digital governmentality)

Definition/ methodology:

Elite and global profit and resource extraction,
fragile and collapsed states, plus risk of terrorism

(Stage: Neoliberal statebuilding)

Definition/ methodology:

Layer 4 Subaltern claims for equality, justice/ sustainability

(Stage: Post-1960s Expanded rights claims)

Definition/ methodology:

Layer 3 Domestic and international inequality

(Stage: Twentieth-century welfare state/ decolonisation)

Definition/ methodology:

Layer 2 Territorial War between sovereign states and empires, Multilateral Institutions, International Law and

(Stage: Twentieth-century liberal internationalism)

Definition/ methodology:

Territorial War between sovereign states and empires Geopolitical balancing/International Conferences/

$\begin{array}{ll}\text { Layer } 1 & \text { Territorial War between } \\ \text { (Stage: Nineteenth-century balance of power) }\end{array}$

Definition/ methodology:

Diplomacy/ Treaties/ Balance of Power

[Negative Peace/ Methodological Nationalism]

Multilateral, multiscalar, transnational, networks of NGOs, transversal, multivertical movements, institutions, and International Conventions; mobility, expanded rights, and global justice

[Peace with Global Justice/ Methodological Everydayism]

State security and the free flow of economic resources, global capital and the neoliberal state, plus the development of new technologies of power; basic rights and resilience; new technological advances

[Neoliberal Peace/ Methodological Neoliberalism]

Social democracy, multilateral institutions, International law and the expansion of international conventions, civil and global civil society, concepts like Human Security and sustainable development; human rights, participatory democracy, economic and social rights

[Post-Liberal Peace: Hybrid/ Everyday Peace Methodological Everydayism]

The welfare state, socialism, with an international framework of exchange, probably including multilateral Institutions, International Law and International Conventions; economic and social Rights

[Positive Peace/ Methodological Liberalism] International Conventions, Development of the League of Nations/ UN system/ EU and other regional organisations; human rights and representative democracy

[Liberal Peace/ Methodological Liberalism]

Figure 1. The IPA.

trying to improve them: and secondly the circulation of micro-powers that navigate around such entrenched blockages and the system they produce (that is, closely entangled IPA and counterpeace frameworks). ${ }^{126}$

Figure 1 outlines the IPA in more detail, connecting its various layers with a framework for peacemaking at each stage. It also indicates the methodological approach for each stage (related to methodological nationalism, liberalism, and everydayism), and a definition of peace related to each stage.

This architecture, reaching as far back as and spanning 'Plato to NATO' (or the warfare state to the internationalised welfare state, the liberal peace and onwards to the globally governed

${ }^{126}$ Michel Foucault, The History of Sexuality, trans. Robert Hurley (London, UK: Penguin, 1990 [orig. pub. 1979]), vol. 1, pp. 92-3. 
neoliberal state) needs stabilising and augmenting by global justice dimensions according to the critical-historical synthesis and argument this article has outlined. ${ }^{127}$ This raises the question of how to overcome blockages to peace and a subsequent counter-peace system, a general loss of legitimacy, and the growing confusion over ad hoc sovereign responses to global problems. ${ }^{128}$ Even now, with new issues and political actors emerging and expanding subaltern claims for rights partly via the platform the IPA has provided, and given the enormous force-relations war has been indicative of, it is hard to see how historically the IPA might have taken a different form. The theoretical-historical architecture this exploration of the IPA denotes is unstable, torn by its internal contradictions and a changing global environment. It represents a complex and exceptionally fragile interlocking framework of norms, tools, institutions, laws, rights, and balances, related to the evolution of international order, often developing retrospectively after its many breakdowns. Stage six is bifurcated firstly between conceptions of global justice that connect peace processes, peacekeeping, peacebuilding, and conflict transformation, with historical and distributive forms of justice, or secondly, digital governmentality. The scene is thus set for further critical developments to stabilise the existing layers of the architecture and produce new layers designed to deal with the changing dimensions of war and conflict.

Acknowledgements. Thanks to several anonymous reviewers for their useful interjections. This article is based on a forthcoming book, The Grand Design (Oxford University Press, 2021).

Oliver P. Richmond is Research Professor in International Relations, Peace and Conflict Studies at the University of Manchester, UK. He is also International Professor at Dublin City University, Ireland, and Distinguished Visiting Professor at the University of Tubingen, Germany. His publications include Peace Formation and Political Order in Conflict Affected Societies (Oxford University Press, 2016); Failed Statebuilding (Yale University Press, 2014). He is editor of the Palgrave book series, Rethinking Peace and Conflict Studies, and co-editor of the Journal, Peacebuilding.

\footnotetext{
${ }^{127} \mathrm{Nicl}$ Vaughan-Williams, 'International relations and the "problem of history"'; Richard Devetak, 'The project of modernity and IR theory', Millennium, 24:1 (1995), p. 35.

${ }^{128}$ See, for example, 'Fortaleza Declaration', Sixth BRICS Summit, 2014.
}

Cite this article: Richmond, O. P. 2021. The evolution of the international peace architecture. European Journal of International Security 6, 379-400. https://doi.org/10.1017/eis.2021.12 